\title{
GENOTYPING, SEROTYPING AND DETERMINATION OF MATING-TYPE OF Cryptococcus neoformans CLINICAL ISOLATES FROM SÃO PAULO STATE, BRAZIL
}

\author{
Marcelo Teruyuki MATSUMOTO(1), Ana Marisa FUSCO-ALMEIDA(1), Lilian Cristiane BAEZA(1), Márcia de Souza Carvalho MELHEM(2) \\ \& Maria José Soares MENDES-GIANNINI(1)
}

\begin{abstract}
SUMMARY
The basidiomycetous yeast Cryptococcus neoformans is an important fungal pathogen mainly in immunocompromised patients. In this study, 47 clinical isolates of $C$. neoformans from regions of São Paulo State were studied serologically by using the Crypto Check Iatron RM 304-K kit, their genetic diversity was estimated by PCR-fingerprinting with a microsatellite-specific sequence $(\mathrm{GACA})_{4}$, RAPD with primer 6 (Amersham Pharmacia Biotech), PCR-restriction fragment length polymorphism (RFLP) analysis of the phospholipase B gene (PLB1) digested with AvaI and mating type analysis by PCR. All 47 strains isolated from HIV positive patients included in this study were serotype A and MAT $\alpha$. The majority of the isolates (45/47) were VNI and only two were VNII by PCR-fingerprinting and PCR-RFLP analysis. High degree of homogeneity was observed when (GACA) was used, being highly correlated (> 0.9). In contrast, the RAPD analysis was more heterogeneous with higher number of molecular profiles. By PCRRFLP, no new molecular type was found, enhancing the suggestion that the differences based on conserved gene as PLB1, can be resultant of ongoing divergent evolution within the $C$. neoformans complex, into the current eight subtypes. Our results furnish new information on the molecular epidemiology of $C$. neoformans in the southeast region of Brazil.
\end{abstract}

KEYWORDS: Cryptococcus; Epidemiology; Mating type; RAPD; PCR fingerprinting; RFLP

\section{INTRODUCTION}

Cryptococcus neoformans is an encapsulated yeast agent of human and animal cryptococcosis ${ }^{30,31}$. This opportunistic fungal pathogen has a worldwide distribution and is responsible for life-threatening infections of the central nervous system, mainly in patients with AIDS $^{11,39}$. Two distinct species have been recognized: $C$. neoformans with two varieties, var. grubii (serotype A), var. neoformans (serotype D) and the hybrid serotype $\mathrm{AD}$ and $C$. gattii, including serotypes $\mathrm{B}$ and $\mathrm{C}^{20,28}$.

Human infection is acquired by inhalation of infectious propagules such as desiccated yeast cells or maybe basidiospores from environment sources $^{21,35,44}$. C. neoformans is a heterothallic basidiomycete that exists as two mating types, $\alpha$ and a, being determined by single locus MAT, with two alleles ${ }^{24}$. One of the most interesting features of $C$. neoformans is the imbalance between mating-types prevalence in the environmental as well as clinical isolates. Almost all isolates have been found to be mating-type $\alpha^{27}$. However, some rare isolates identified as MAT $\alpha / a$ are considered to be occasional diploid or aneuploid strains ${ }^{13,34}$.

Most infections, in immunocompromised hosts, are caused by $C$. neoformans var. grubii ${ }^{11,39}$. In contrast, C. neoformans var. gattii generally affects immunocompetent hosts ${ }^{43}$. The incidence of cryptococcosis varies according to the population, the region and the period studied. In Brazil, from 1980 to 2002, 215,810 AIDS patients were registered, among whom $6 \%$ had cryptococcosis at the time of diagnosis $^{9}$ and São Paulo is the state with the highest rate of this disease. The majority of the Brazilian clinical and environmental isolates have shown to be serotype A with exception in north and northeastern regions where the serotype B is endemic $\mathrm{c}^{1,4,41,46}$.

Epidemiological studies on cryptococcosis are essential to understand the biology of this fungus in order to improve current therapy against this infection. Several molecular typing methods have been used in epidemiological analyses of clinical and/or environmental isolates of $C$. neoformans, including karyotyping, PCR fingerprinting, random amplified polymorphic DNA (RAPD), restriction fragment length polymorphism (RFLP) and amplified fragment length polymorphism (AFLP) , $7,8,10,12,16,22,26,37,45$. PCR-fingerprinting using mini (M13) or microsatellite $\left[(\mathrm{GACA})_{4}\right]$ specific sequences as single primers and RFLP (PLB1 and URA5 genes) methods have grouped global isolates of $C$. neoformans into eight major molecular types ${ }^{32,37,38}$. Likely, BOEKHOUT et al. using AFLP analysis grouped into six major AFLP groups $^{8}$. FRANZOT et al. using CNRE-1 RFLP analysis and URA5 sequencing found low genetic diversity among Brazilian isolates ${ }^{19}$;

(1) Faculdade de Ciências Farmacêuticas, Departamento de Análises Clínicas. Disciplina de Micologia Clínica, Universidade Estadual Paulista, Araraquara, SP, Brasil.

(2) Instituto Adolfo Lutz, São Paulo, SP, Brasil.

Correspondence to: Maria José Soares Mendes Giannini, R. Expedicionários do Brasil 1621, Caixa Postal 502, 14801-192 Araraquara, SP, Brasil. Fax: +55-16-3301.6547. E-mail: giannini@fcfar.unesp.br 
MATSUMOTO, M.T.; FUSCO-ALMEIDA, A.M.; BAEZA, L.C.; MELHEM, M.S.C. \& MENDES-GIANNINI, M.J.S. - Genotyping, serotyping and determination of mating-type of Cryptococcus neoformans clinical isolates from São Paulo State, Brazil. Rev. Inst. Med. trop. S. Paulo, 49(1): 41-47, 2007.

conversely, HORTA et al. have found great differences in RAPD profiles $^{23}$. On the other hand, ALMEIDA et al. showed the presence of $22 \mathrm{EK}$ and 15 RAPD profiles that were highly related ${ }^{2}$.

Phospholipases are found in a wide range of organisms, including both pathogenic and nonpathogenic species of yeasts and moulds ${ }^{6,15,33,36}$. The phospholipase B (PLB1) gene of C. neoformans has been described as important virulence factor in a mouse and rabbit and as interesting target for molecular typing of $C$. neoformans via PCR-RFLP analysis ${ }^{15,32}$. However until the present moment, there are not available data about the molecular epidemiology of $C$. neoformans using PLB1RFLP method in Brazil.

Even though $C$. neoformans is a leading cause of life-threatening mycotic infection among AIDS patients in Brazil, a small amount of works have studied this molecular epidemiology. In light of this, we analyzed clinical isolates of $C$. neoformans from several regions of São Paulo State to evaluate serotypes, genetic variability using PCRfingerprinting with (GACA) $)_{4}$ oligonucleotide, RAPD with primer 6 , PLB1-RFLP and mating type analysis by PCR.

\section{MATERIAL AND METHODS}

Fungal isolates: Forty-seven strains of $C$. neoformans were isolated at intervals; from thirty-five AIDS patients from São José do Rio Preto, Santos, Araraquara and Ribeirão Preto, from various geographic areas of São Paulo State, Brazil, during the pre-highly active antiretroviral therapy (HAART) period. These isolates were maintained in the Culture Collection of the Instituto Adolfo Lutz laboratory, a Public Health National Reference Center, located in six different cities in São Paulo State. The C. neoformans cultures were grown at $30{ }^{\circ} \mathrm{C}$ on Sabouraud dextrose agar with chloramphenicol. The isolates were identified by conventional methods to genus, species and variety. Serotyping was performed by slide agglutination (Crypto Check Iatron kit, Tokyo, Japan), following the manufacturer's instructions.

DNA isolation: Genomic DNA was extracted and purified by a slight modification of the method of DEL SAL et al. ${ }^{17}$. Briefly, C. neoformans isolates were grown on Sabouraud's dextrose agar at $30{ }^{\circ} \mathrm{C}$ for 48 hours and two loopfuls of cells from the culture were suspended in YEPD medium with $2.9 \% \mathrm{NaCl}$ and then incubated at $30{ }^{\circ} \mathrm{C}$ overnight. Cells were harvested and suspended in CES $\left(20 \mathrm{mmol} \mathrm{l}^{-1}\right.$ sodium citrate; $50 \mathrm{mmol} \mathrm{l}^{-1}$ EDTA pH 8.0; $0.9 \mathrm{~mol} \mathrm{l}^{-1}$ sorbitol) containing Novozym 234 (NovoNordisk, from Trichoderma harzianum, Denmark). The suspension was incubated at $37^{\circ} \mathrm{C}$ for three hours, and spheroplasts were collected by centrifugation. DNA was isolated by lysing the spheroplasts in TEN buffer with $1 \%$ SDS ( $1 \mathrm{~mol} \mathrm{l}^{-1}$ Tris-base; 0.5 mol l-1 $^{-1}$ EDTA; $1 \mathrm{~mol} \mathrm{l}^{-1} \mathrm{NaCl} ; 1 \%$ SDS). Chloroform-isoamyl alcohol (24:1) was then added, shaken and centrifuged for 13 minutes at $12000 \mathrm{rpm}$ and the aqueous phase was transferred to a new tube. To precipitate the DNA, isopropanol (1:1) was added and incubated at $-20{ }^{\circ} \mathrm{C}$ for 30 minutes. The DNA pellet was washed with $70 \%$ ethanol, centrifuged and air-dried. Finally, the DNA was resuspended in $80 \mu \mathrm{L} \mathrm{TE} \mathrm{(40} \mathrm{mmol} \mathrm{l}^{-1}$ Tris-base, $2 \mathrm{mmol} \mathrm{l}^{-1}$ EDTA).

RAPD and PCR-fingerprinting: Oligonucleotides of the microsatellite-specific sequence (GACA) ${ }_{4}$ were used as single primers in the PCR, as described by MEYER et al. ${ }^{38}$. The amplification reactions were performed in a volume of $25 \mu \mathrm{L}$, using the Ready-to-Go RAPD Kit according to the manufacturer's instructions. PCR was performed for 35 cycles in a Perkin-Elmer Thermal cycler (model GeneAmp PCR System 9700), each consisting of with 20 seconds of denaturation at $94{ }^{\circ} \mathrm{C}$, one minute annealing at $50{ }^{\circ} \mathrm{C}$, and 20 seconds extension at $72{ }^{\circ} \mathrm{C}$, followed by a final extension cycle for six minutes at $72{ }^{\circ} \mathrm{C}$. Amplification products were separated by electrophoresis on $2 \%$ agarose gels in $1 \mathrm{X}$ TBE buffer (Tris-borate-EDTA) at $150 \mathrm{~V}$ for 2.5 hours, stained with ethidium bromide and then visualized under UV light.

The RAPD analysis was carried out using primer six (5'CCCGTCAGCA-3'; Amersham Pharmacia Biotech) in a volume of $25 \mu \mathrm{L}$, using the Ready-to-Go RAPD Kit according to the manufacturer's instructions. The following cycle conditions were used: initial denaturation at $95{ }^{\circ} \mathrm{C}$ for five minutes, followed by 45 cycles of denaturation at $95{ }^{\circ} \mathrm{C}$ for one minute, annealing at $36{ }^{\circ} \mathrm{C}$ for one minute and amplification at $72{ }^{\circ} \mathrm{C}$ for two minutes, and a final extension at $72{ }^{\circ} \mathrm{C}$ for 10 minutes. Amplification products were separated by electrophoresis, on $2 \%$ agarose gels in $1 \mathrm{X}$ TBE buffer at $150 \mathrm{~V}$ for 2.5 hours and stained with ethidium bromide and then visualized under UV light.

PCR-RFLP analysis of the PLB1 gene: The PLB1 fragment was amplified by PCR, in a final volume of $50 \mu \mathrm{L}$, digested with AvaI in accordance with LATOUCHE et al. ${ }^{32}$ and was separated by electrophoresis on $3 \%$ agarose gel at $100 \mathrm{~V}$ for 5.5 hours.

Determination of mating type: Mating type was established by PCR using two primer pairs, specific for mating-type $\alpha$ and $\mathbf{a}$, in accordance with CHATURVEDI et al. ${ }^{13}$. Initial denaturation was done at $95{ }^{\circ} \mathrm{C}$ for three minutes, followed by 30 cycles of denaturation at $94{ }^{\circ} \mathrm{C}$ for one minute, annealing at $57.5^{\circ} \mathrm{C}$ for one minute, amplification at $72{ }^{\circ} \mathrm{C}$ for one minute, and a final extension at $72{ }^{\circ} \mathrm{C}$ for seven minutes, in a GeneAmp PCR System 9700 (Perkin-Elmer). Amplification products were separated by electrophoresis on $2 \%$ agarose gels in $1 \mathrm{X}$ TBE buffer at $120 \mathrm{~V}$ for two hours stained with ethidium bromide and then visualized under UV light.

Reference strains: The following $C$. neoformans standard reference strains representing each major molecular type were used in PCR fingerprinting and PCR-RFLP: WM148 (VNI - serotype A), WM626 (VNII - serotype A), WM628 (VNIII - serotype AD), WM629 (VNIV - serotype D), WM179 (VGI - serotype B), WM178 (VGII - serotype B), WM161 (VGIII - serotype B), WM779 (VGIV - serotype C) ${ }^{37}$.

The C. neoformans strains ATCC 28957 (serotype D, MAT $\alpha$ ) and ATCC 28958 (serotype D, MATa) were used as positive control for determination of mating type by PCR.

Statistical analysis: The computer software GelCompar II (Applied Maths, Version 2.0, Belgium) was used to determine the genetic relatedness of the isolates. Similarity coefficients were calculated by using the Dice Algorithm and cluster analysis was performed by the UPGMA (Unweighted Pair-Group Method Using Arithmetic Averages) tree method.

\section{RESULTS}

Fungal isolates: A total of 47 cryptococcal isolates from four São 
MATSUMOTO, M.T.; FUSCO-ALMEIDA, A.M.; BAEZA, L.C.; MELHEM, M.S.C. \& MENDES-GIANNINI, M.J.S. - Genotyping, serotyping and determination of mating-type of Cryptococcus neoformans clinical isolates from São Paulo State, Brazil. Rev. Inst. Med. trop. S. Paulo, 49(1): 41-47, 2007.

Paulo State districts were recovered from 35 HIV-positive patients, among whom nine $(25 \%)$ had more than one sample taken at the time of diagnosis and during the treatment and $27(75 \%)$ provided single samples. All isolates were identified as C. neoformans var. grubii, serotype A.

Determination of Mating Type by PCR: The MAT $\alpha$ and MATa specific primers pair were used to amplify specific fragments of $101 \mathrm{bp}$ and $117 \mathrm{bp}$, respectively. Epidemiological analysis of the mating type showed $100 \%$ prevalence of MAT $\alpha$ in all four regions (Fig. 1).

PLB1-RFLP, PCR-fingerprinting and RAPD analysis: The PLB1RFLP and (GACA) - PCR fingerprinting analysis were carried out to separate the strains of $C$. neoformans into eight major molecular types (Fig. 2A).

The RFLP profiles generated showed prevalence of $95.7 \%(45 / 47)$ of the molecular type VNI and only two VNII (4.3\%) (Fig. 2B).

Random primer 6 and a single primer specific to microsatellite repeats $(\mathrm{GACA})_{4}$ were used to amplify DNA polymorphisms within the cryptococcal genome. RAPD profiles and PCR fingerprinting types were assigned according to the major bands. For both (GACA) and random primer 6 , all visible and well-defined bands identified visually and confirmed by the software were included in the analysis (Fig. 2B). Similarity dendrogram analysis obtained with (GACA) $)_{4}$ showed a high overall homogeneity among the 47 isolates from São Paulo State. The mean coefficient similarity value of the strains was $0.98 \pm 0.04$. Two major groups were formed. The group I, corresponding $C$. neoformans var. grubii (VNI type strains), was clustered 45 isolates (95.7\%) in three profiles with similarity around 0.94 . The second minor group (II) with only two VNII type strains was formed showing correlation of 0.84 with the VNI group (Fig. 3). In contrast, the dendrogram based on RAPD profiles with primer 6 showed more heterogeneous profile. The mean coefficient similarity of the strains was $0.84 \pm 0.15$. A total of 14 profiles were distributed in three major groups that showed similarity around 0.55 . The group I had approximately 0.8 of similarity and clustered 41 strains (87.2\%) in 11 profiles, all molecular type VNI. The two strains VNII were grouped in a distinct cluster (group II) as obtained with $(\mathrm{GACA})_{4}$ showing correlation around 0.7 with the group I. Finally, the group III containing four isolates and two profiles included strains from Santos and Araraquara districts that had 100\% similarity with PCR fingerprinting but when compared with RAPD showed a low similarity coefficient $(<0.6)$ with the other two groups (Fig. 4).

\section{DISCUSSION}

The epidemiology of $C$. neoformans complex has been extensively explored worldwide but in Brazil, specially in São Paulo State, the data on molecular epidemiology remain scarce and more information would help to elucidate the distribution of the major molecular types among Brazilian isolates. The genetic structure of $C$. neoformans is very complex and the employment of new primers in RAPD, as well as other molecular tools, such as the PCR-RFLP method based on PLB1 gene in this work, are interesting and important to elucidate the epidemiology. All isolates included in this study were recovered from HIV-positive patients and identified as C. neoformans var. grubii, serotype A. This finding is consistent with previous studies showing that the majority of the cases of cryptococcosis in immunocompromised hosts, mainly patients with AIDS, in Brazil as well as worldwide, are caused by serotype $\mathrm{A}^{11,12,39,41}$. NISHIKAWA et al. serotyped $467 C$. neoformans isolates from clinical and environmental sources in Brazil. Serotype A was more prevalent mainly in southern and southeast regions while the serotype B was predominant in north and northeastern region $^{41}$.

Several typing approaches have been used in epidemiological studies to characterize and investigate the genetic structure of $C$. neoformans isolates. All C. neoformans isolates were grouped into one major molecular type VNI (var. grubii, serotype A) with (GACA) PCR fingerprinting and confirmed by PLB1-RFLP, with exception of two strains that were identified as VNII, from Santos district. Our results are similar to previous studies that found VNI type strains as the commonest molecular type. An IberoAmerican study performed with strains from nine countries including Brazil showed prevalence of VNI among 340 C. neoformans strains. Specifically, 66 Brazilian strains were included revealing only three molecular types being VNI more predominant with $82.3 \%$ followed by VGII $(13.6 \%)$ and VNII $(3.0 \%)^{37}$. CASALI et al., in an important survey of Brazilian cryptococcal isolates from the southern region of the country, investigated 105 clinical and 19 environmental isolates and also verified a predominance of $C$. neoformans var. grubii molecular type $\mathrm{VNI}^{12}$. Although with low number of strains, the RAPD analysis showed notable heterogeneity. While the (GACA) ${ }_{4}$ PCR fingerprinting yielded four profiles distributed in two major groups with mean similarity value of $0.98 \pm 0.04$, the primer 6 RAPD yielded 14 profiles in three major groups with mean similarity of $0.84 \pm 0.15$ value. Moreover, four isolates that were high similar with PCR-fingerprinting showed low correlation with primer 6 . These results can have occurred because the primer probably hybridizes with less conserved regions of the genomic DNA generating more polymorphisms ${ }^{3}$. In a previous study, twenty two arbitrary polymerase chain reaction primers were tested in clinical and environmental isolates from the Brazilian state Rio Grande do Sul among them eight confirmed the genetic polymorphism ${ }^{23}$. In another, numerous distinguishable subtypes were identified among strains recovered from AIDS patients ${ }^{26}$.

Nine patients investigated in this study had more than one sample taken at the time of diagnosis and during the treatment. Almost all serial isolates showed identical genotypes independent of the time of isolation. Only one patient with two serial isolates had genotype variety with primer 6 but not with (GACA). However the value of coefficient similarity was $>0.9$ suggesting that microevolution probably occurred.

The PCR-RFLP method based on PLB1 gene is of great importance because highlights differences based on partial sequence of a single virulence gene, while PCR-fingerprinting, on the other hand, amplifies mostly noncoding DNA sequences across the whole genome ${ }^{14,32}$. In our knowledge, there are not reports evolving Brazilian samples using this method. The PLB1-RFLP was applied associated with PCRfingerprinting to differentiate the strains into eight molecular types previously described as well as verify the possible existence of a new molecular subtype. In the present work, VNI was prevalent in 45/47 isolates $(95.7 \%)$ while VNII was $2 / 47$ (4.3\%), none new molecular subtype was found. Our results enhance previous data that suggest the differences based on more conserved genes as PLB 1 or URA- 5 by 
MATSUMOTO, M.T.; FUSCO-ALMEIDA, A.M.; BAEZA, L.C.; MELHEM, M.S.C. \& MENDES-GIANNINI, M.J.S. - Genotyping, serotyping and determination of mating-type of Cryptococcus neoformans clinical isolates from São Paulo State, Brazil. Rev. Inst. Med. trop. S. Paulo, 49(1): 41-47, 2007.

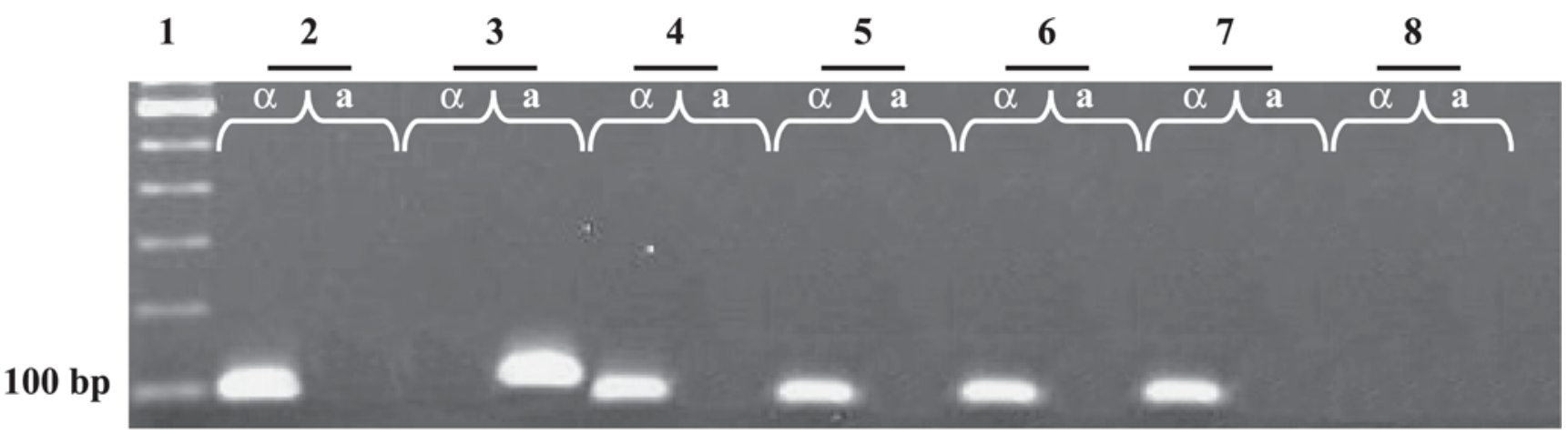

Fig. 1 - PCR amplification of C. neoformans isolates for determination of mating type. Lane 1, molecular weight marker (Gibco 100bp); 2, ATCC 28957 (MAT $\boldsymbol{\alpha}$ ); 3 , ATCC 28958 (MATa); 47, clinical isolates; 8 , negative control.

A

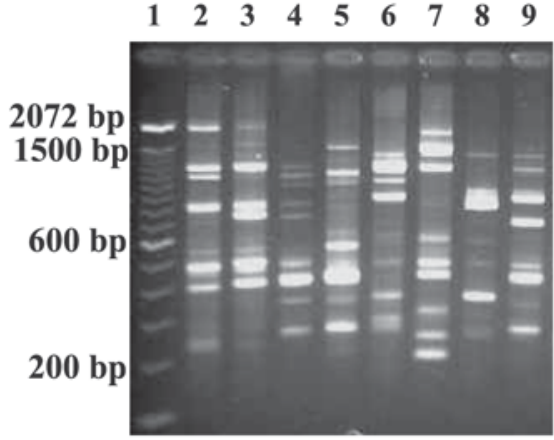

II
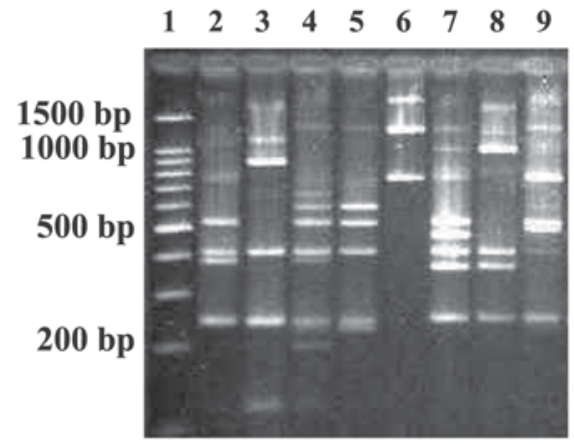
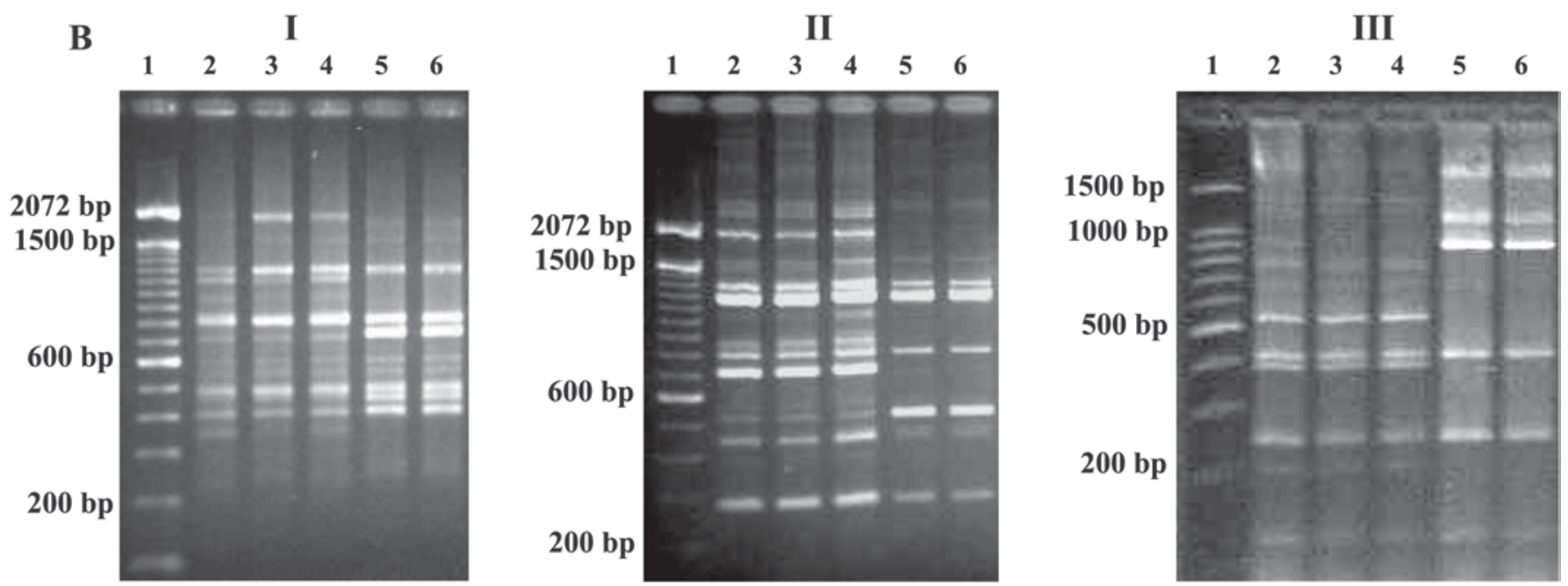

Fig. 2 - A. PCR fingerprinting with primer (GACA) 4 (AI) and PLB1-RFLP with AvaI (AII) patterns of C. neoformans. Lane 1*, molecular weight marker; 2-5, molecular types VNI, VNII, VNIII, VNIV; 6-9, molecular types VGI, VGII, VGIII, VGIV - B. Representative gel of (GACA) -PCR fingerprinting (BI), Primer 6-RAPD (BII) and PLB1-RFLP (BIII) from clinical isolates of C. neoformans. Lane $1^{*}$, molecular weight marker; 2-4, clinical isolates 377, 379 and 387 (molecular type VNI, serotype A); 5-6, clinical isolates 382 and 384 (molecular type VNII, serotype A). * Molecular weight marker (Gibco 100bp) to the (GACA) -PCR fingerprinting (AI and BI) and Primer 6-RAPD (BII). Molecular weight marker (Promega 100bp) to the PLB1-RFLP (AII and BIII). 


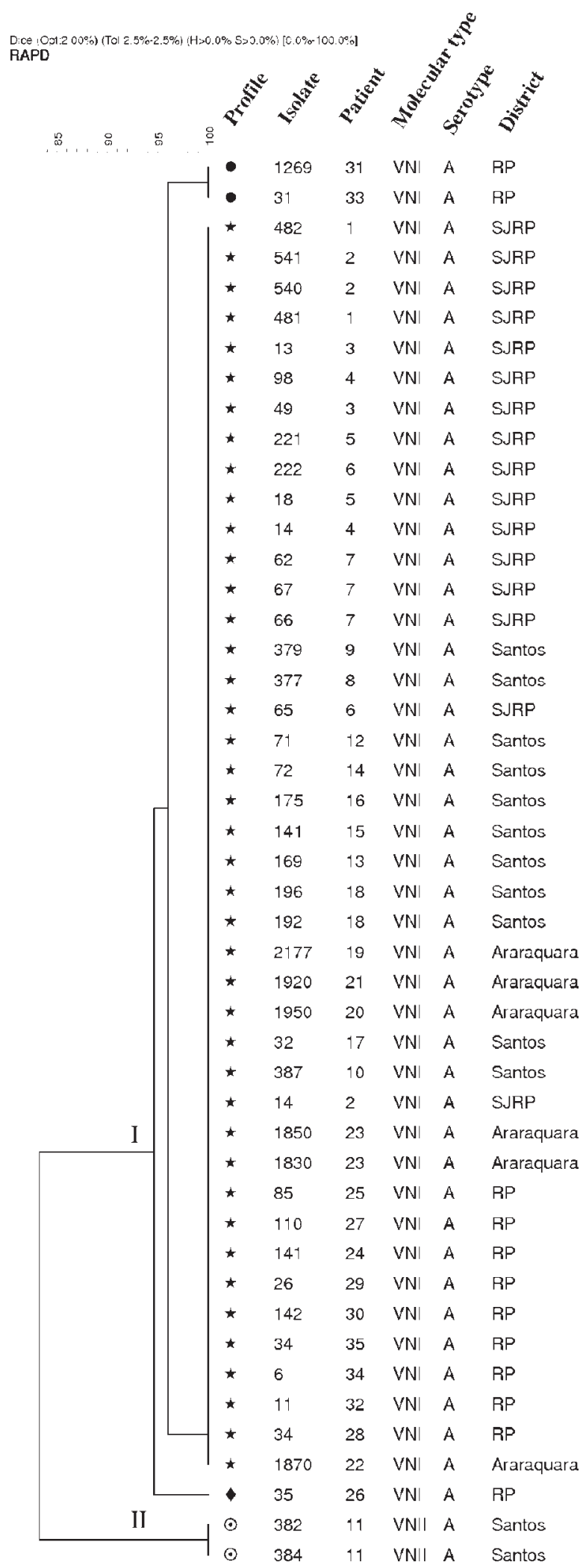

Fig. 3 - Dendrogram of the PCR-fingerprinting patterns obtained from C. neoformans isolates with primer (GACA)

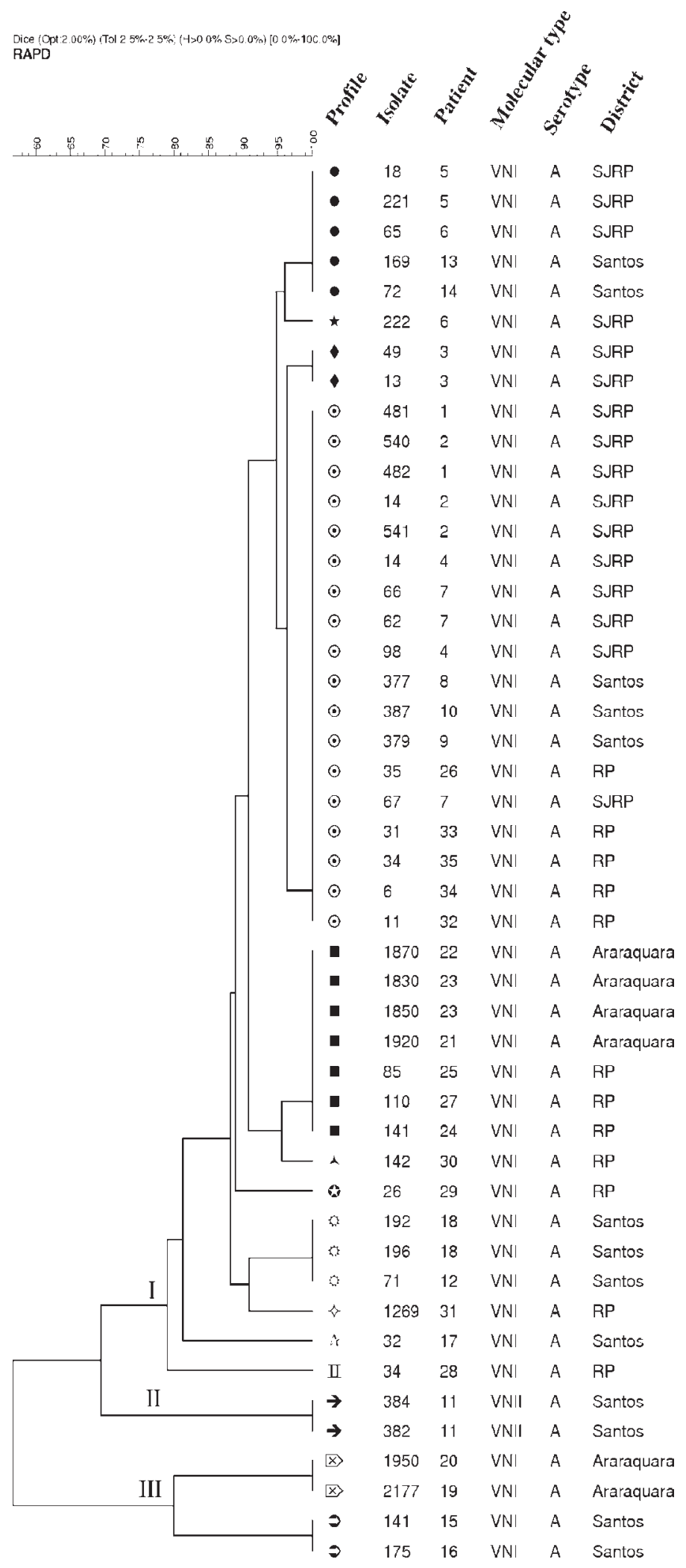

Fig. 4 - Dendrogram of the RAPD patterns obtained from C. neoformans isolates with primer 6 
MATSUMOTO, M.T.; FUSCO-ALMEIDA, A.M.; BAEZA, L.C.; MELHEM, M.S.C. \& MENDES-GIANNINI, M.J.S. - Genotyping, serotyping and determination of mating-type of Cryptococcus neoformans clinical isolates from São Paulo State, Brazil. Rev. Inst. Med. trop. S. Paulo, 49(1): 41-47, 2007.

PCR-RFLP can be resultant of ongoing divergent evolution within the C. neoformans complex, into the current eight subtypes and not only coincidental $^{32}$.

Mating type $\alpha$-specific primer was used here and yielded a 101bp MAT $\alpha$ fragment in all cases, showing that all $C$. neoformans isolates were MAT $\alpha$, consistently with a previous study showing that MAT $\alpha$ is more frequent than MATa among clinical as well as environmental isolates ${ }^{12,25,27,42}$. Information about the mating-types of $C$. neoformans strains is important for an understanding of their ecology and virulence. It has been reported that MAT $\alpha$ is more virulent than the opposite type MATa $^{29}$. Moreover, in coinfection with both mating types, the MATo strains more likely disseminate to the central nervous system which might explain the prevalence among the clinical isolates ${ }^{40}$.

In conclusion, the results obtained in this study add new information to the available data on molecular epidemiology of $C$. neoformans in the southeast region of Brazil.

\section{RESUMO}

\section{Genotipagem, sorotipagem e determinação de mating-type de isolados clínicos de Cryptococcus neoformans do Estado de São Paulo, Brasil}

Cryptococcus neoformans, pertencente à classe dos basidiomicetos, é um importante patógeno, principalmente em pacientes imunocomprometidos. Neste estudo, 47 isolados clínicos de $C$. neoformans de várias regiões do Estado de São Paulo foram avaliados quanto aos sorotipos e ao mating-type por PCR. A diversidade genética foi analisada por PCR-fingerprinting com a seqüência iniciadora específica para regiões microssatélite (GACA) $)_{4}$, RAPD com o iniciador 6 (Amersham Pharmacia Biotech) e por RFLP do gene PLB1 digerido com AvaI. Todos os isolados foram obtidos de pacientes HIV positivos e identificados como sorotipo A e MAT $\alpha$. A maioria dos isolados pertencia ao tipo molecular VNI (45/47) e apenas dois foram VNII quando analisados por PCR-fingerprinting e PCR-RFLP. Homogeneidade alta foi obtida com o iniciador (GACA) 4 com a maioria dos isolados apresentando correlação alta $(>0.9)$. Os resultados do RAPD, por sua vez, revelaram maior heterogeneidade com número maior de perfis moleculares. Por PCR-RFLP, nenhum tipo molecular novo foi encontrado, realçando a idéia de que em genes conservados como PLB1, as diferenças podem ser resultantes de divergências evolutivas dentro do complexo $C$. neoformans, separando os isolados nos oito subtipos moleculares já estabelecidos. Nossos resultados fornecem novas informações sobre a epidemiologia molecular de $C$. neoformans na região sudeste do Brasil.

\section{ACKNOWLEDGMENT}

This work was financial supported by PADC-FCF-UNESP, CNPq and FAPESP.

\section{REFERENCES}

1. ABEGG, M.A.; CELLA, F.L.; FAGANELLO, J. et al. - Cryptococcus neoformans and Cryptococcus gattii isolated from the excreta of psittaciformes in a southern Brazilian zoological garden. Mycopathologia, 161: 83-91, 2006.
2. ALMEIDA, A.M.F.; MATSUMOTO, M.T.; BAEZA, L.C. et al. - Molecular typing and antifungal susceptibility of clinical sequential isolates of Cryptococcus neoformans from São Paulo State, Brazil. FEMS Yeast Res., 2006 (in press).

3. BAEZA, L.C.; MATSUMOTO, M.T.; FUSCO-ALMEIDA, A.M. \& MENDESGIANNINI M.J.S. - Strain differentiation of Trichophyton rubrum by randomly amplified polymorphic DNA and analysis of ribosomal DNA non transcribed spacer. J. med. Microbiol., 55: 429-436, 2006.

4. BARONI, F.A.; PAULA, C.R.; SILVA, E.G. et al. - Cryptococcus neoformans strains isolated from church towers in Rio de Janeiro city, RJ, Brazil. Rev. Inst. Med. trop. S. Paulo, 48: 71-75, 2006.

5. BARRETO DE OLIVEIRA, M.T.; BOEKHOUT, T.; THEELEN, B. et al. - Cryptococcus neoformans shows a remarkable genotypic diversity in Brazil. J. clin. Microbiol., 42: 1356-1359, 2004

6. BIRCH, M.; ROBSON, G.; LAW, D. \& DENNING, D.W. - Evidence of multiple extracellular phospholipase activities of Aspergillus fumigatus. Infect. Immun., 64: 751-755, 1996.

7. BOEKHOUT, T.; VAN BELKUM, A.; LEENDERS, A.C. et al. - Molecular typing of Cryptococcus neoformans: taxonomic and epidemiological aspects. Int. J. syst. Bact., 47: 432-442, 1997.

8. BOEKHOUT, T.; THEELEN, B.; DIAZ, M. et al. - Hibrid genotypes in pathogenic yeast Cryptocococcus neoformans. Microbiology, 147: 891-907, 2001.

9. BRASIL - Ministério da Saúde. Dados e pesquisa em DST e AIDS. Brasília, Coordenação do Programa Nacional de DST/AIDS, 2002. (Site: www.aids.gov.br).

10. CALVO, B.M.; COLOMBO, A.L.; FISCHMAN, O. et al. - Antifungal susceptibilities, varieties, and electrophoretic karyotypes of clinical isolates of Cryptococcus neoformans from Brazil, Chile, and Venezuela. J. clin. Microbiol., 39: 2348-2350, 2001.

11. CASADEVALL, A. \& PERFECT, J.R. - Cryptococcus neoformans. Washington, ASM Press, 1998.

12. CASALI, A.K.; GOULART, L.; ROSA E SILVA, L.K. et al. - Molecular typing of clinical and environmental Cryptococcus neoformans isolates in the Brazilian State Rio Grande do Sul. FEMS Yeast Res., 3: 405-415, 2003.

13. CHATURVEDI, S.; RODEGHIER, B.; FAN, J. et al. - Direct PCR of Cryptococcus neoformans MAT $\alpha$ and MATa pheromone to determine mating type, ploidy, and variety: a tool for epidemiological and molecular pathogenesis studies. J. clin. Microbiol., 38: 2007-2009, 2000

14. COGLIATI, M.; HALLARÍA, M.; TORTORANO, A.M. \& VIVIANI, M.A. - Genotyping Cryptococcus neoformans var. neoformans with specific primers designed from PCRfingerprinting bands sequenced using a modified PCR-based strategy. Med. Mycol., 38: $97-103,2000$

15. COX, G.M.; McDADE, H.C.; CHEN, S.C.A. et al. - Extracellular phospholipase activity is a virulence factor for Cryptococcus neoformans. Molec. Microbiol., 39: 166$175,2001$.

16. DELGADO, A.C.; TAGUCHI, H.; MIKAMI, Y. et al. - Human cryptococcosis: relationship of environmental and clinical strains of Cryptococcus neoformans var. neoformans from urban and rural areas. Mycopathologia, 1: 7-11, 2005.

17. DEL SAL, G.; MANFIOLETTI, G. \& SCHNEIDER, C. - The CTAB-DNA precipitation method: a common mini-scale preparation of template DNA from phagemids, phages or plasmids suitable for sequencing. BioTechniques, 7: 514-520, 1989.

18. ELLIS, D.; MARRIOTT, D.; HAJJEH, R.A. et al. - Epidemiology: surveillance of fungal infections. Med. Mycol., 38 (suppl. 1): 173-182, 2000. 
MATSUMOTO, M.T.; FUSCO-ALMEIDA, A.M.; BAEZA, L.C.; MELHEM, M.S.C. \& MENDES-GIANNINI, M.J.S. - Genotyping, serotyping and determination of mating-type of Cryptococcus neoformans clinical isolates from São Paulo State, Brazil. Rev. Inst. Med. trop. S. Paulo, 49(1): 41-47, 2007.

19. FRANZOT, S.P.; HAMDAN, J.S.; CURRIE, B.P. \& CASADEVALL, A. - Molecular epidemiology of Cryptococcus neoformans in Brazil and the United States: evidence for both local genetic differences and a global clonal population structure. J. clin. Microbiol., 35: 2243-2251, 1997.

20. FRANZOT, S.P.; SALKIN, I.F. \& CASADEVALL, A. - Cryptococcus neoformans var. grubii: separate varietal status for Cryptococcus neoformans serotype A isolates. J. clin. Microbiol., 37: 838-840, 1999.

21. FRASER, J.A.; SUBARAN, R.L.; NICHOLS, C.B. \& HEITMAN, J. - Recapitulation of the sexual cycle of the primary fungal pathogen Cryptococcus neoformans var. gattii: implications for an outbreak on Vancouver Island, Canada. Eukaryot. Cell, 2: 1036$1045,2003$.

22. GARCIA-HERMOSO, D.; JANBON, G. \& DROMER, F. - Epidemiological evidence for dormant Cryptococcus neoformans infection. J. clin. Microbiol., 37: 3204-3209, 1999.

23. HORTA, J.A.; STAATS, C.C.; CASALI, A.K. et al. - Epidemiological aspects of clinical and environmental Cryptococcus neoformans isolates in the Brazilian State Rio Grande do Sul. Med. Mycol., 40: 565-571, 2002.

24. HULL, C.M. \& HEITMAN, J. - Genetics of Cryptococcus neoformans. Ann. Rev. Genet., 36: $557-615,2002$.

25. IDNURM, A.; BAHN, Y.S.; NIELSEN, K. et al. - Deciphering the model pathogenic fungus Cryptococcus neoformans. Nature Rev. Microbiol., 3: 753-64, 2005.

26. IGREJA, R.P.; LAZERA, M.S.; WANKE, B. et al. - Molecular epidemiology of Cryptococcus neoformans isolates from AIDS patients of the Brazilian city, Rio de Janeiro. Med. Mycol., 42: 229-238, 2004.

27. KWON-CHUNG, K.J. \& BENNETT, J.E. - Distribution of $\alpha$ and a mating-types of Cryptococcus neoformans among natural and clinical isolates. Amer. J. Epidem., 108: $337-340,1978$

28. KWON-CHUNG, K.J.; BOEKHOUT, T.; FELL, J.W. \& DIAZ, M. - Proposal to conserve the name Cryptococcus gattii against $C$. hondurianus and C. bacillisporus (Basidiomycota, Hymenomycetes, Tremellomycetidae). Taxon, 51: 804-806, 2002.

29. KWON-CHUNG, K.J.; WICKES, B.L.; STOCKMAN, L. et al. - Virulence, serotype, and molecular characteristics of environmental strains of Cryptococcus neoformans var. gattii. Infect. Immun., 60: 1869-1874, 1992.

30. KWON-CHUNG, K.J. - A new genus, Filobasidiella, the perfect state of Cryptococcus neoformans. Mycologia, 67: 1197-1200, 1975.

31. KWON-CHUNG, K.J. - A new species of Filobasidiella, the sexual state of Cryptococcus neoformans B and C serotypes. Mycologia, 68: 943-946, 1976.

32. LATOUCHE, G.N.; HUYNH, M.; SORRELL, T.C. \& MEYER, W. - PCR-restriction fragment length polymorphism analysis of the phospholipase B gene (PLB1) for subtyping of Cryptococcus neoformans isolates. Appl. environ. Microbiol., 69: 20802086, 2003.
33. LEE, K.S.; PATTON, J.L.; FIDO, M. et al. - The Saccharomyces cerevisiae PLBI gene encodes a protein required for lysophospholipase and phospholipase B activity. J. biol. Chem., 269: 19725-19730, 1994.

34. LENGELER, K.B.; COX, G.M. \& HETMAN, J. - Serotype AD strains of Cryptococcus neoformans are diploid or aneuploid and are heterozygous at the mating type locus. Infect. Immun., 69: 115-122, 2001.

35. LIN, X. \& HEITMAN, J. - The biology of the Cryptococcus neoformans species complex. Ann.. Rev. Microbiol., 60: 69-105, 2006.

36. MASUDA, N.; KITAMURA, N. \& SAITO, K. - Primary structure of protein moiety of Penicillium notatum phospholipase B deduced from the cDNA. Europ. J. Biochem., 202: 783-787, 1991.

37. MEYER, W.; CASTANEDA, A.; JACKSON, S. et al. - Molecular typing of IberoAmerican Cryptococcus neoformans isolates. Emerg. infect. Dis., 9: 189-195, 2003.

38. MEYER, W.; MARSZEWSKA, K.; AMIRMOSTOFIAN, M. et al. - Molecular typing of global isolates of Cryptococcus neoformans var. neoformans by polymerase chain reaction fingerprinting and randomly amplified polymorphic DNA - a pilot study to standardize techniques on which to base a detailed epidemiological survey. Electrophoresis, 20: 1790-1799, 1999.

39. MITCHELL, T.G. \& PERFECT, J. - Cryptococosis in the era of Aids - 100 Years after the discovery of Cryptococcus neoformans. Clin. Microbiol. Rev., 8: 515-548, 1995.

40. NIELSEN, K.; COX, G.M.; LITVINTSEVA, A.P. et al. - Cryptococcus neoformans \{alpha\} strains preferentially disseminate to the central nervous system during coinfection. Infect. Immun., 73: 4922-4933, 2005.

41. NISHIKAWA, M.M.; LAZERA, M.S.; BARBOSA, G.G. et al. - Serotyping of 467 Cryptococcus neoformans isolates from clinical and environmental sources in Brazil: analysis of host and regional patterns. J. clin. Microbiol., 41: 73-77, 2003.

42. OHKUSU, M.; TANGONAN, N.; TAKEO, K. et al. - Serotyping, mating type and ploidy of Cryptococcus neoformans strains isolated from patients in Brazil. Rev. Inst. Med. trop. S. Paulo, 44: 299-302, 2002.

43. SORREL, T.C. - Cryptococcus neoformans variedade gattii. Med. Mycol., 39: 155-168, 2001 .

44. SUKROONGREUNG, S.; KITINIYOM, K.; NILAKUL, C. \& TANTIMAVANICH, S. Pathogenicity of basidiospores of Filobasidiella neoformans var. neoformans. Med. Mycol., 36: 419-424, 1998.

45. TRILLES, L.; LAZERA, M.; WANKE, B.; THEELEN, B. \& BOEKOUT, T. - Genetic characterization of environmental isolates of Cryptococcus neoformans species complex from Brazil. J. clin. Microbiol., 41: 383-390, 2003.

46. VIDOTTO, V.; MELHEM, M.; PUKINSKAS, S. et al. - Extracellular enzymatic activity and serotype of Cryptococcus neoformans strains isolated from AIDS patients in Brazil. Rev. iberoamer. Micol., 22: 29-33, 2005.

Received: 12 May 2006

Accepted: 16 August 2006 